\title{
Teaching Video NeuroImage: One Bedside Test, 2 Clinical Signs
}

\section{One Vestibular, the Other Ocular Motor}

Michael Strupp, MD, Claudia Frenzel, Nicolina Goldschagg, MD, and G. Michael Halmagyi, MD

Neurology ${ }^{\circledR}$ 2021;97:e541-e542. doi:10.1212/WNL.0000000000012080

Figure Caloric Irrigation and Video Head Impulse Test

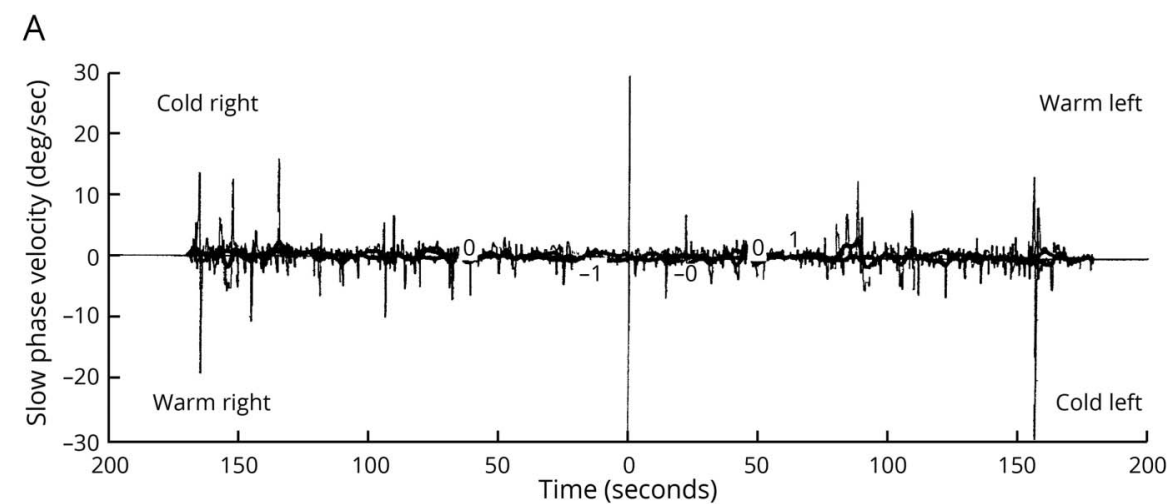

B

Lateral impulse test: 02/07/2020 10:28 Test operator: DEMO GNO
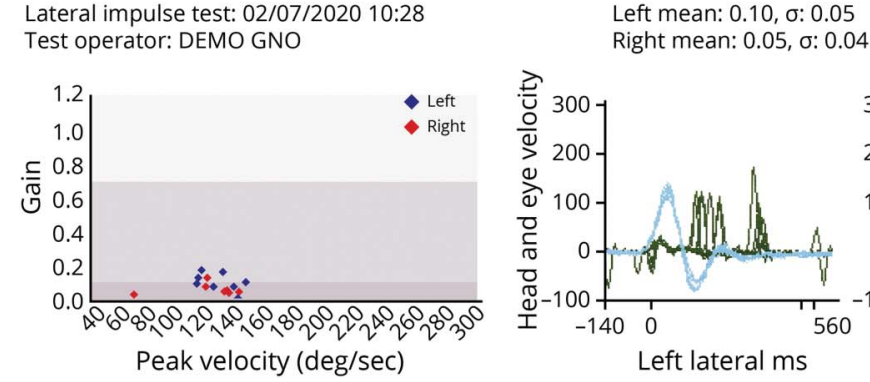

Left mean: 0.10, ఠ: 0.05

Right mean: 0.05, ఠ: 0.04

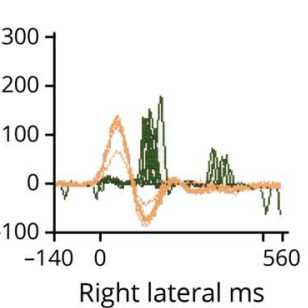

(A) Caloric irrigation and (B) video head impulse test show a severe vestibulo-ocular reflex deficit.

A 60-year-old patient had progressive imbalance. Examination revealed saccadic smooth pursuit, downbeat nystagmus, ataxia of stance and gait, and reduced vibration sense. Video head impulse and caloric testing both showed vestibulo-ocular reflex (VOR) deficits (figure). The patient has cerebellar ataxia with neuronopathy and vestibular areflexia syndrome. ${ }^{1,2}$ Slow head turns while looking at an earth-fixed target produce saccadic rather than smooth compensatory eye movements (Videos 1 ) due to impairment of both the VOR and smooth pursuit (the visually enhanced VOR): 1 simple bedside test, 2 clinical signs, and 1 precise diagnosis.

Correspondence

Dr. Strupp

Michael.Strupp@

med.uni-muenchen.de

\section{Study Funding}

No targeted funding reported.

\section{Disclosure}

M. Strupp is Joint Chief Editor of the Journal of Neurology, Editor in Chief of Frontiers of Neurootology, and Section Editor of F1000; has received speaker's honoraria from Abbott, Actelion,

From the Department of Neurology and German Center for Vertigo and Balance Disorders (M.S., C.F., N.G.), Ludwig Maximilians University, Campus Grosshadern, Munich, Germany; and Department of Neurology (G.M.H.), Royal Prince Alfred Hospital, University of Sydney, Australia.

Go to Neurology.org/N for full disclosures. Funding information and disclosures deemed relevant by the authors, if any, are provided at the end of the article. 
Auris Medical, Biogen, Eisai, Grünenthal, GSK, Henning Pharma, Interacoustics, Merck, MSD, Otometrics, Pierre-Fabre, TEVA, $\mathrm{UCB}$, and Viatris; is a shareholder of IntraBio; acts as a consultant for Abbott, Actelion, Auris Medical, Heel, IntraBio, and Sensorion; and is the distributor of M-glasses, and the positional vertigo App. C. Frenzel, N. Goldschagg, and G.M. Halmagyi do not have any disclosures. Go to Neurology.org/N for full disclosures.

\section{Appendix Authors}

\begin{tabular}{|c|c|c|}
\hline Name & Location & Contribution \\
\hline $\begin{array}{l}\text { Michael } \\
\text { Strupp, MD }\end{array}$ & $\begin{array}{l}\text { Department of Neurology and } \\
\text { German Center for Vertigo and } \\
\text { Balance Disorders (DSGZ), } \\
\text { Ludwig-Maximilians University, } \\
\text { Munich, Campus Grosshadern, } \\
\text { Munich, Germany }\end{array}$ & $\begin{array}{l}\text { Observation, conception, } \\
\text { recruitment and } \\
\text { examination of the patient, } \\
\text { interpretation of the data, } \\
\text { drafting the manuscript }\end{array}$ \\
\hline $\begin{array}{l}\text { Claudia } \\
\text { Frenzel }\end{array}$ & $\begin{array}{l}\text { Department of Neurology } \\
\text { Ludwig-Maximilians University, } \\
\text { Munich, Campus Grosshadern, } \\
\text { Munich, Germany }\end{array}$ & $\begin{array}{l}\text { Neuro-opthalmological } \\
\text { examination of the patient, } \\
\text { interpretation of the data, } \\
\text { drafting the manuscript }\end{array}$ \\
\hline
\end{tabular}

Appendix (continued)

\begin{tabular}{|c|c|c|}
\hline Name & Location & Contribution \\
\hline $\begin{array}{l}\text { Nicolina } \\
\text { Goldschagg, } \\
\text { MD }\end{array}$ & $\begin{array}{l}\text { Department of Neurology } \\
\text { and German Center for } \\
\text { Vertigo and Balance } \\
\text { Disorders (DSGZ), Ludwig- } \\
\text { Maximilians University, } \\
\text { Munich, Campus } \\
\text { Grosshadern, Munich, } \\
\text { Germany }\end{array}$ & $\begin{array}{l}\text { Observation, examination of } \\
\text { the patient, taking of the } \\
\text { video interpretation of the } \\
\text { data, drafting the } \\
\text { manuscript }\end{array}$ \\
\hline $\begin{array}{l}\text { G. Michael } \\
\text { Halmagyi, } \\
\text { MD }\end{array}$ & $\begin{array}{l}\text { Department of Neurology, } \\
\text { Royal Prince Alfred Hospital, } \\
\text { University of Sydney, } \\
\text { Sydney, } \\
\text { Australia }\end{array}$ & $\begin{array}{l}\text { Interpretation of the data, } \\
\text { drafting the manuscript }\end{array}$ \\
\hline \multicolumn{3}{|c|}{ References } \\
\hline & $\begin{array}{l}\text { z DJ, Roberts L, Mclean CA, MacDo } \\
\text { diagnostic criteria for cerebellar atax } \\
\text { ndrome (CANVAS). Neurol Clin Pr }\end{array}$ & $\begin{array}{l}\text { ougall HG, Halmagyi GM, Storey E. } \\
\text { xia with neuropathy and vestibular } \\
\text { act. } 2016 ; 6(1): 61-68 \text {. }\end{array}$ \\
\hline $\begin{array}{l}\text { 2. Boesch } S \\
\text { factor } 1 \mathrm{~g} \\
6(3): \mathrm{e} 43\end{array}$ & $\begin{array}{l}\text { M, Nance MA. Intronic pentanucled } \\
\text { ene }(R F C 1) \text { is a major cause of adult }\end{array}$ & $\begin{array}{l}\text { otide expansion in the replication } \\
\text { t-onset ataxia. Neurol Genet. 2020; }\end{array}$ \\
\hline
\end{tabular}




\section{Neurology}

\section{Teaching Video NeuroImage: One Bedside Test, 2 Clinical Signs: One Vestibular, the Other Ocular Motor}

Michael Strupp, Claudia Frenzel, Nicolina Goldschagg, et al.

Neurology 2021;97;e541-e542 Published Online before print April 23, 2021

DOI 10.1212/WNL.0000000000012080

This information is current as of April 23, 2021

\section{Updated Information \&} Services

\section{References}

Subspecialty Collections

Permissions \& Licensing

Reprints including high resolution figures, can be found at: http://n.neurology.org/content/97/5/e541.full

This article cites 2 articles, 2 of which you can access for free at: http://n.neurology.org/content/97/5/e541.full\#ref-list-1

This article, along with others on similar topics, appears in the following collection(s):

\section{All Neurotology}

http://n.neurology.org/cgi/collection/all_neurotology

Gait disorders/ataxia

http://n.neurology.org/cgi/collection/gait_disorders_ataxia

Vertigo

http://n.neurology.org/cgi/collection/vertigo

Information about reproducing this article in parts (figures,tables) or in its entirety can be found online at:

http://www.neurology.org/about/about_the_journal\#permissions

Information about ordering reprints can be found online:

http://n.neurology.org/subscribers/advertise

Neurology ${ }^{\circledR}$ is the official journal of the American Academy of Neurology. Published continuously since 1951 , it is now a weekly with 48 issues per year. Copyright @ 2021 American Academy of Neurology. All rights reserved. Print ISSN: 0028-3878. Online ISSN: 1526-632X.

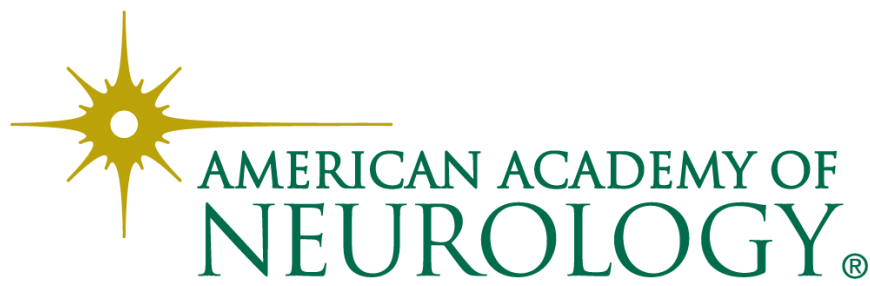

